\title{
Welcome to the National Wetlands Research Center Library: Successful Research Begins @your library
}

\section{Hours of Operation and Collection Access}

The NWRC library offers 24-hour access to the online catalog and selected research tools at http:// www.nwrc.usgs.gov/library.htm. For detailed information on current holdings, journals, indexes, and databases, please consult the library's Web site. Employees of the NWRC are allowed access to the library 7 days a week from 5 a.m. through midnight. The librarian is available for assistance Monday through Friday from 8 a.m. to 4:30 p.m., excluding Federal holidays.

Users can search library holdings via the online catalog or by visiting the library. Staff may browse the collections, which are organized according to the Library of Congress classification system, or search the periodical holdings, which are arranged alphabetically by title. New journal issues are placed in the Current Periodicals review area before being shelved with the main collection.

\section{Resources}

Collections include the following subject specialties: forested wetland ecology, fire science, spatial analysis, remote sensing, modeling, statistical analysis, marsh and coastal prairie management and restoration, plant communities, habitats, aquatic ecosystems, climate change, wetland loss, hurricanes, nutrient dynamics, and limnology.

Library holdings include books, e-books, print periodicals, full-text electronic journals, VHS tapes,

DVDs, CDs, audio tapes, microforms, and databases. Topical collections include:

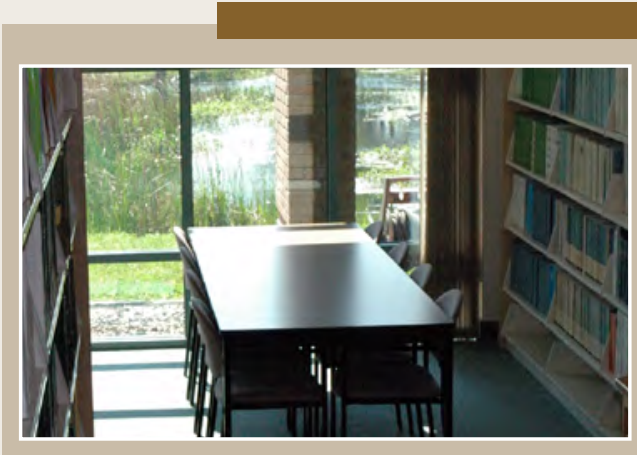

A USGS Library Dedicated to Wetland Science
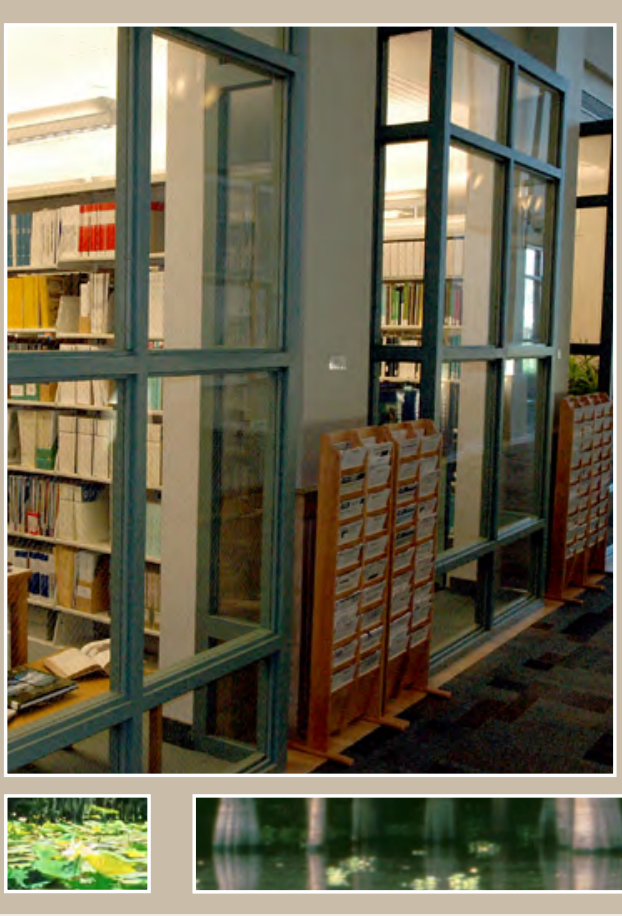

—Reprints (subject specific publications and those authored by NWRC scientists)

- Scientific and technical reports (for example, U.S. Fish and Wildlife Service reports, National Biological Service reports, USGS Biological Resources Discipline reports)

- Statistics reference materials (in-library use)

\section{About the Library}

The National Wetlands Research Center (NWRC) library is part of the U.S. Geological Survey (USGS) and is the only USGS library dedicated to wetland science. The mission of the NWRC library is to support the research and information needs of scientists, managers, and support personnel by providing a specialized, scientific collection of library materials and related information services that are responsive to and reflect internal and external customer needs and work processes.

The librarian arranges for access to resources needed to perform research and administrative tasks and organizes information products. The NWRC library participates in international cataloging and resource sharing that allows libraries from throughout the world to borrow from its collections and lend to NWRC. This sharing of materials facilitates the research of other governmental agencies, universities, and those interested in the study of wetlands. 
Employees may use their network logon and password to access electronic resources, including databases and journals, from the library or from their office computers. Software applications and equipment for digitizing photographs and slides and for creating files in portable document format (PDF) are available in the library, along with a variety of other information and media equipment. The library has designated areas for small group meetings and for work or study.

Display windows highlight the library's holdings and new acquisitions. Suggestions for future exhibits are welcomed. Shelving located inside the library holds free copies of literature such as consumer information, government reports, and reprints. Publications authored by NWRC staff are on permanent display in front of the library. Distribution copies of articles are available upon request.

\section{Special Collections}

The NWRC library houses several unique collections:

-Robert G. Wetzel Collection in wetland ecology and limnology contains some 1,500 books and 60 journal titles, primarily in English, but also in several other languages, including Russian, German, Japanese, Spanish, Portuguese, French, and Italian. This is a circulating collection.

\section{-Jacob Valentine Archival} Collection provides materials covering historical wildlife refuges located in Louisiana and Mississippi. This collection is noncirculating.

\section{-The National Wetlands Research Center Archives include information on and about NWRC since its establishment in 1975 as part of the U.S. Fish and Wildlife Service, Office of Biological Services. This collection is noncirculating.}

\section{Borrowing}

Federal and contract staff of the NWRC may borrow materials housed within the NWRC library's circulating collections. Noncirculating materials are limited to in-library use. Permanent Federal staff may also borrow directly from the USGS Central Region library located in Denver, Colo. Staff interested in obtaining direct borrowing privileges from the regional library can contact the NWRC librarian to arrange for a library card.

Interlibrary loan (ILL) and document delivery services are used to obtain material not available through the NWRC library. Staff requests may be submitted in person, electronically, or by telephone.

\section{Reference and Research}

A knowledgeable, full-time professional librarian is available to assist with locating library materials and using digital and print resources. The librarian also offers expert assistance with complex reference questions and provides current awareness and alerting services through e-mail. The online catalog, research databases, and other electronic resources provide access to well-organized information.

\section{Visitor Information}

Visitors are welcome to use the NWRC library Monday through Friday from 8:30 a.m. to 3:30 p.m., excluding Federal holidays. Computers have software applications for word processing and creating spreadsheets, databases, and presentation materials, and they include access to the Internet, e-mail, and library catalog. There are no fees for printing. Visitors may use materials in the library and make a limited number of photocopies. The library does not charge for copies.

\section{Partners and Student Interns}

At the discretion of the NWRC librarian, agency and other partners may borrow library material from circulating collections. The NWRC library offers limited ILL services to partners. Reference and research services are extended to partners; however, staff research requirements receive priority. Upper-level student interns may receive restricted borrowing privileges with approval of their NWRC sponsor and the librarian. Students are expected to seek reference and ILL services from their home university.

\section{For more information contact}

\author{
Linda Broussard \\ U.S. Geological Survey \\ National Wetlands Research Center \\ 700 Cajundome Blvd. \\ Lafayette, LA 70506-3152 \\ Phone 337-266-8692 \\ Fax 337-266-8841 \\ nwrclibrary@usgs.gov \\ http://www.nwrc.usgs.gov/library.htm
}

The logo@your library is a registered trademark of the American Library

Association, and its use does not imply endorsement by the U.S. Government.

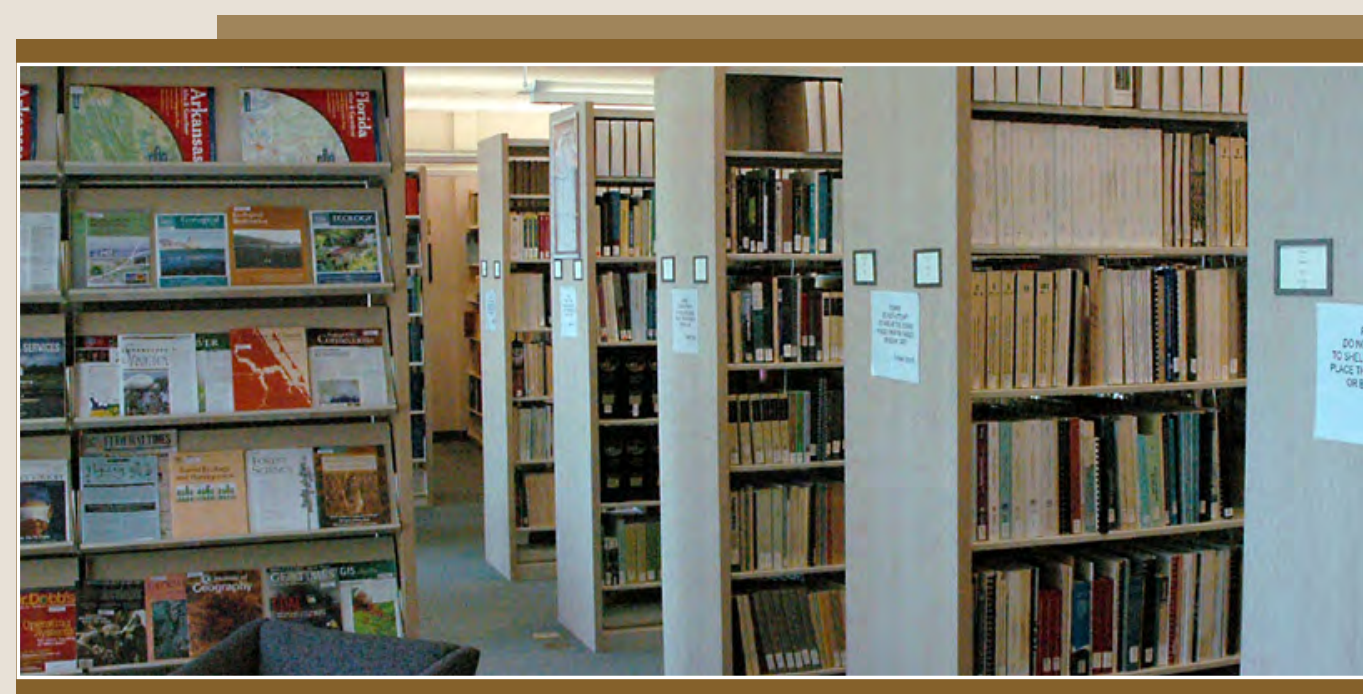

